building is in the Flizabethan style of architecture, and cost $£ 167,000$. It con. tains 500 beds, is 700 feet long, and 450 feet deep, covering six acres. Its most prominent feature is two handsome towers, which rise from the east and weat sides of the central or administrative blook, to a height of 150 feet, the upper 30 foet being of wood. On Tharsday, 16th October, at four o'clock in the afternoon, the wood-work of the west tower was observed to be on fire, having been ignited by a spark from a neighbouring chimney. Every endearour was made to quench the fire with buckets of water obtained from a large tank immediately below the burning woodwork. It was soon, howerer, evident that the woodwork of the tower was doomed, and that moreover the surrounding buildings were in great jeopardy. The Asylum Fire Brigade had been by this time called ont, and directed their efforts to isolating the fire by guarding the roofs of the main buildings in the vioinity of the tower. In this they were successful, for although the roof several times caught fire, it was promptly extingnished. The roofs were kept safe by deluging with water the burning rafters and sparks which fell upon them. At half-past six the danger to the surrounding buildings was considered past, the wooden portion having subsided within the stonework of the tower, which now bore a striking resemblance to a huge smelting furnace. The doors leading from the bottom of the tower had been built up with turf. The Glasgow Fire Brigade arrived at about seven o'clock and speedily extinguished the fire within the tower.

The Asylum was fortunate in having a well trained fire brigade, which when fire did occur, proved of essential service. When the fire brigade was called out, all patients and attendants in the grounds, workshops, laundry, \&c., were brought to their respective wards, those in the division next the burning tower being distributed amongst the others until the danger was past. There was really no excitement amongst the patients, and the order that prevailed was very striking. The ringing of the tea bell and the issuing of that meal at the usual hour, had a reassuring effect upon all. The patients were quietly put to bed at eight o'clock; those in the division next the tower, with a portion of their clothing on ; and next day the routine of the asylum went on as usual.

\title{
AFTER CARE OF CONVALESCENTS.
}

Another meeting of the Association for assisting insane convalesconts (See Journal for Oct., 1879), was held on the 27th November. Lord Shaftesbury has kindly consented to become the Patron. A Committee of ladies was appointed, who enter heartily into the work. The question of providing a Distinct Home was discussed. It was decided not to proceed with this at present, but to be content with endeavouring to provide temporary homes in cottages and other houses, and finding suitable places for servants willing to go out to service.

In connection with this movement, we extract from the last Roport of the Now York City Lunatic Asylum (Blackwell's Island) the following paragraphs (by Dr. Strew), headed "Situations Procured for Patients" : -

"In an Asylum of this kind there are many patients who after recovery find it difficult, or almost impossible, to procure employment. Mrs. George Riley has deeply interested herself in behalf of these, and through her efforts has succeeded in procuring situations for at least one dozen of these rosovered patients, who are all doing well, and by their good behaviour rewarding her for the interest manifested in their behalf, and although no longer amenabie to the rules and regulations of the Asylum, she continues to keep a watchful and supervising eye over them.

"It is to be hoped that many other friends of these unfortunate patients will be induced to follow the laudsble example of this lady, and enlist in this good cause. 
"In connection with this subject, I would respectfully suggest that a small appropriation be made by your Honourable Board, to enable some of these re. covered patients, who are friendless and without means, to once more pursue their usual arocations, and again face the world. For instance, a poor servantgirl is sent to the Asylum wearing on her person all her worldly effects; she is a case of acute mania, and has already torn or destroyed, or so damaged her clothing that it is no longer fit to be worn. After a lapse of time she recovers, is restored to reason, and is told that she can leave tbe Asylum. 'I have no clothes to wear, no means to procure a night's lodging or the necessary daily food, until I can obtain a situation,' is her reply. She has no friends. What is to be done in such a case ? To send her to the Alms-house is repugnant to her feelings; to send her to the city penniless is to expose her to temptation. The matron does what she best can as far as supplying her with clothing and making her look as decent as possible under the circumstances, and she leaves the Asylum to again battle with the world. A dollar or two given at this period might be the means of saving her. It is for this class that I make the appeal, and candidly and honestly consider that, in most instances at least, if not in all, this fund would not be misapplied. Heretofore, whatever money has been furnished to these patients has been supplied by myself or the matron, who preferred providing the necessary temporary means of sustenance rather than see them exposed to want."

\title{
INDEX MEDICO-PSYCHOLOGICUS.*
}

\section{JOURNALS AND TRANSACTIONS.}

\author{
Enalish.
}

The Journal of Mental Science. Quarterly.

The Journal of Payohological Medicine and Mental Pathology. SemiAnnual.

Brain. A Journal of Neurology. Quarterly.

\section{Aurrican.}

The American Journal of Insanity. Quarterly.

The Journal of Nerrous and Mental Diseases. Quarterly.

Proceedings of the Association of Medical Officers of American Institutions for Idiotic and Feeble.Minded Persons. Annual.

Neurological Contributions. New York. Quarterly.

The Quarterly Journal of Inebriety. Hartford, Conn., U. S. A.

$$
\text { French. }
$$

Annales M6́dico-Psychologiques. Bi-Monthly.

- Te prorpoee to give some pages of this Bibliography, sccording as our space permits, in future numbers of the Journal. We had irtended to make the Index commence with January. dete 1 h88

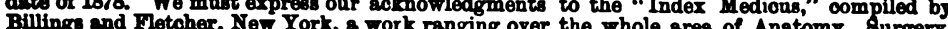
Mediane, Dentinter codract an

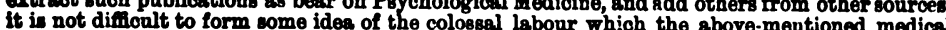
men have undertaken. Wo have tound it diffionlt to included some artiales on Fipilepes Hiteris, Catalepsy, Dipsomanis draw the lin but havo ing works on the phyciology and petholo Oef relinquiah so extensive a range of medioal literatare, important as many of the works are whioh we have exaluded from our catslogre. But, wherever we draw the line of demarcaltion, it munt be arbitterry, becanee no such division exists in nsture,-D. H. T. 